\title{
Design of Local Wisdom Based Resident of Bugis Tribe with Environmental Insights (Study on Supporting Facilities Aspects)
}

\author{
Muhammad Ardi, Mithen Lullulangi, Faizal Amir \\ Engineering Department, Universitas Negeri Makassar, Makassar, Indonesia \\ Email address: \\ m.ardi@unm.ac.id (M. Ardi), mithen@unm.ac.id (M. Lullulangi), faizalamir64@unm.ac.id (F. Amir)

\section{To cite this article:} \\ Muhammad Ardi, Mithen Lullulangi, Faizal Amir. Design of Local Wisdom Based Resident of Bugis Tribe with Environmental Insights \\ (Study on Supporting Facilities Aspects). International Journal of Architecture, Arts and Applications. Vol. 5, No. 4, 2019 , pp. 82-88. \\ doi: 10.11648/j.ijaaa.20190504.11
}

Received: October 19, 2019; Accepted: November 12, 2019; Published: November 19, 2019

\begin{abstract}
This study aims to determine the layout and form of construction of supporting facilities for small, medium and large types of homes based on the local wisdom of the Bugis who are environmentally friendly. The locations of the study are three districts, namely: Bone, Soppeng, and Wajo, by choosing 300 households as respondents. Research variables are supporting facilities, in the form of: (1) septictank, (2) sewerage and dirty water, (3) temporary landfills, and (4) open space, small, medium-sized residential houses, and big. Data collection by questionnaire, and data analysis techniques are qualitative descriptive analysis. The results showed that, the layout and form of construction of supporting facilities for small, medium, and large residential types based on local wisdom of the Bugis Tribe, which were environmentally sound were: (1) the location of the septictank was located in the front yard, the shape of a rectangular construction from brick or reinforced concrete construction equipped with impregnation tank, (2) the location of sewerage and rainwater, in the yard of the side leading to the drainage, the form of open channel construction of masonry, (3) the location of garbage disposal while temporary landfills, in the front yard, the rectangular shape of a brick or concrete construction, and (4) the location of open space, located in the front yard of the house and the side, natural in shape and bounded by masonry.
\end{abstract}

Keywords: Residential House, Local Wisdom, Supporting Facilities, Environmental Insight, Bugis Tribe

\section{Introduction}

Growth and population growth automatically have an impact on the provision of healthy, safe and comfortable homes. In Law Number 32 of 2009 concerning Environmental Protection and Management in principle states that in building a residential that needs to be understood is to utilize the environment as needed and maintain the environment so that it continues to be sustainable [1]. Trainer, states that in building does not use resources nature excessively, natural resources are utilized as needed [2]. Doxiadis in Muhammad Ardi, said that humans have needs such as space, air, temperature, and so on and to take shelter in need of residential buildings as a means of social service [3].

Local wisdom cannot be separated from the construction or design of residential houses. Marfai, stated that local wisdom is another form of environmental ethics and is a set of knowledge obtained through the process and learning of a group of people [4]. Jundiani, explained that: Etymologically, local wisdom consists of two words of wisdom and local. Local means regional and wisdom equal with prudence. In other words, local wisdom can be understood as local ideas, values, the point of views which have a wise characteristic, full of knowledge, have a good value that embedded and followed by its community members. Local wisdom is a local ideas which have a wise characteristic, full of wisdom, have a good value that embeded and followed by its community members. Meanwhile, according to a framework issued by the Social Welfare Ministry, local wisdom is defined as a view of life and knowledge as well as the various life strategies in the form of people's activities in answering 
multiple problems regarding in the fulfilment of their needs [5]. Effendi at al, stated that: More specifically, a sustainable environment is concluded as a condition of balance, resilience, and interrelation that enables humans to meet their needs without exceeding the capacity of the supporting ecosystem and be able to regenerate to continue to be able to meet the needs of the future [6].

Furthermore Muhammad Ardi, explained that a sustainable environment will form a good diversity of ecosystems and diversity of ecosystems creates a diversity of life forms [5]. Based on the previous description, the purpose of this study is to determine the location and form of construction of supporting facilities, namely: (1) septictank, (2) sewerage and rainwater, (3) temporary landfills, and (4) open space, small type, medium type, and large type of residence based on local wisdom of the Bugis Tribe who are environmentally friendly.

The theory underlying this study is described as follows. In Law No. 4 Year on Housing and Settlements it is said that, a house is a building that functions as a residence or residence and a means of family formation [7]. Haryanto, said that In a broad sense, the house is not just a building (structural), but also a place of residence that meets the conditions of decent living, viewed from various aspects of community life. The house can be understood as a refuge, to enjoy life, rest and have fun with family [8]

Frick and Widmer in Muhammad Ardi, stated that a dwelling house is a place of residence of people who meet the conditions of a decent life, carry out their lives, and carry out a process of socialization when someone is introduced to the norms and customs that apply in a society [3]. Muhammad Ardi, at al. basically states that the residence is part of the settlement which is the environment where humans live to carry out life that is equipped with social, economic, cultural, and service infrastructure which is a subsystem of the city as a whole [5].

Tasdyanto, and Hamzah, stated that local wisdom is a source of knowledge that is held dynamically, develops and is passed on by certain populations that are integrated with their understanding of the surrounding nature and culture [9]. Adyana, basically stated that local wisdom is a local superiority that relies on values, norms, ethics, knowledge, technology, and behavior owned by a group of people and is traditionally institutionalized which is used to overcome life and life problems [10]. Hamzah, explained that the knowledge of local communities that had accumulated and formed throughout the history of human life had a very big role because it became the basis for humans to interact with their environment [11].

Environmental sanitation cannot be separated from a house. Sanitation in the residential environment is generally called housing support facilities. Environmental sanitation, according to David, is an attempt to control oneself from all human physical factors that might cause things that are detrimental to the physical development of health and endurance of human life [12]. Notoatmodjo, stated that environmental sanitation is an environmental health status that includes, housing, sewage disposal, clean water supply and so on [13]. Franceys and Reed, stated that environmental sanitation is a collection and disposal system of human waste (septictank), liquid waste, disposing of waste so that it does not endanger individuals and society [14].

Khairil, states that The living environment includes the biotic or living matter environment and the abiotic or inanimate environment. Simply put, in the environment there are natural resources, human resources, and artificial resources [15]. Adnani, divides the environment into 3 parts namely: (1) Biological Environment (2) Physical environment, and (3) Social environment [16]. Sustainable development (development enabled) by the World Commissionon Environment Development (WCED), is development to meet current needs, without having to reduce future generations to meet their needs [17]. Mesaki, explained that in the subsequent development sustainable not only in natural resources, but also for humans [18].

\section{Reserch Method}

The locations of the study were three districts, which were selected by purposive sampling method, namely: Kabupaten Bone, Soppeng, and Wajo. Research respondents of 300 people were also selected by purposive sampling method. The variable of concern is the development of the design and construction of supporting facilities for small, medium and large types of houses consisting of: (1) septic tanks, (2) temporary landfills (TPS), (3) sewerage systems and rainwater, and (4) openSpace. The research instruments consisted of: (1) questionnaire location and form of construction of small, medium and large type of septic tank houses, (2) questionnaire for location and form of construction of TPS for small, medium and large type houses, (3) questionnaire for location and form of construction sewerage and rainwater for small, medium and large type houses, and (4) questionnaire for the location and form of openSpace construction for small, medium and large type houses. Data collection is done by giving four questionnaires to respondents to answer. Analysis of the data used is a qualitative descriptive analysis, then proceed with the design process.

\section{Results and Discussion}

\subsection{Location of Septictank for Small, Medium and Large Type of Dwelling Houses}

Respondent data regarding the location of Septitank, can be seen in the table 1 . 
Table 1. Location of Septic Tanks for Small, Medium and Large Type Residential Houses.

\begin{tabular}{lllll}
\hline Number & Description & Statement & Frequency & Percentage \\
\hline 1 & Front yard & Strongly agree & 280 & 93,33 \\
2 & Side yard of the front of the house & Agree & 20 & 6,67 \\
3 & Backyard & Disagree & 0 & 0 \\
4 & Side yard of the house & Strongly disagree & 0 & 0 \\
5 & Total & & 300 & 100 \\
\hline
\end{tabular}

Source: Research Results.

Data obtained from 300 respondents are described as follows. 280 respondents (93.33\%) stated that the location of a small type of septictank (type 54 and 60) based on the local wisdom of the Bugis is on the front yard. A total of 20 respondents $(6.67 \%)$ stated the location of the septictank in the side yard of the front of the house. The reasons underlying the respondents in terms of the local wisdom of the Bugis are: (a) the front makes it easy to drain if at one time the septictank is full of feces or does not function properly, (b) easily controlled and maintained, and (c) foul air those sourced from septictank have no smell because they are neutralized by large volumes of outside air. In the local wisdom of the Bugis there is no prohibition on placing septictank in the back and sides of houses. Septictank placed in residential buildings (under the floor) are not allowed at all. The underlying reasons are: (a) feces are no longer allowed to be together (one place) with the occupants of the house, (b) cause odor in the house, and (c) it is difficult to maintain. Seen from a technical and environmental perspective, it seems to be in line with the local wisdom of the Bugis. Therefore it can be concluded that in terms of the local wisdom of the Bugis tribe, the location of the septictank of small, medium and large type of dwelling house is in the front yard of the house, the side yard of the front of the house. If where in the house there is more than one toilet which is quite far apart, it can make more than one septictank.

\subsection{Location of Dirt and Rainwater Drains for Small, Medium and Large Type of Residential Homes}

Respondent data regarding dirty water disposal, can be seen in the table 2.

Table 2. Location of Disposal of Dirty and Rainwater Drains of Small, Medium and Large Type of Residential Homes.

\begin{tabular}{|c|c|c|c|c|}
\hline Number & Description & Statement & Frequency & Percentage \\
\hline 1 & The right and left side of the house leads to the front & Strongly agree & 293 & 97,66 \\
\hline 2 & The back leads to the side yard of the house & Agree & 7 & 2,34 \\
\hline 3 & To the backyard & Disagree & 0 & 0 \\
\hline 4 & To the home page & Strongly disagree & 0 & 0 \\
\hline 5 & Total & & 300 & 100 \\
\hline
\end{tabular}

Source: Research Results.

Data obtained from 300 respondents are described as follows. A total of 293 respondents $(97.66 \%)$ stated that the location of sewerage and rainwater of small type residential houses (types 54 and 60) based on local wisdom of the Bugis Tribe was on the right and left side of the house leading to the front to a more low, ie to the drain. A total of 7 respondents $(2.34 \%)$ stated that the location of sewerage and rainwater was at the back leading to the side yard of the house if the yard was large enough. Reasons underlying the respondents from the local wisdom side of the Bugis Tribe are: (a) dirty water and rain water easily flow into residential ducts, (b) dirty water and rain water do not inundate the house yard, (c) dirty water and rainwater do not inundate under the house, (d) does not make the yard muddy, and (e) does not cause a foul odor. Viewed from the technical side, and the location of the sewerage system and rainwater of small, medium and large type of residential houses is in line with the local wisdom of the Bugis tribe. Therefore it can be concluded that the location of dirty and rain water drains of small, medium and large type of residence based on local wisdom of the Bugis Tribe is on the right and left side of the residence. The direction of sewerage and rainwater drainage is forward, ie at the lower part of the soil or land elevation or leading to entrance to the drainage channel or drainage.

\subsection{Location of Temporary Trash Disposal (TPS) Small, Medium and Large Type Residential Houses}

Respondent data concerning temporary landfills, can be seen in the table 3 .

Table 3. Location of Temporary, Small and Large Type of Temporary Garbage Disposal (TPS).

\begin{tabular}{|c|c|c|c|c|}
\hline Number & Description & Statement & Frequency & Percentage \\
\hline 1 & The front of the home page & Strongly agree & 296 & 98,66 \\
\hline 2 & The side of the house & Agree & 4 & 1,34 \\
\hline 3 & Backyard & Disagree & 0 & 0 \\
\hline 4 & Any place on the home page & Strongly disagree & 0 & 0 \\
\hline 5 & Total & & 300 & 100 \\
\hline
\end{tabular}

Source: Research Results. 
Data obtained from 300 respondents are described as follows. A total of 296 respondents $(98.66 \%)$ stated that the location of the TPS of small type houses (types 54 and 60) based on the local wisdom of the Bugis was at the front of the home page. The TPS position, which is a bit far from the building of the house. A total of 4 respondents (1.34\%) stated that the location of the TPS was a house if the large yard was on the side of the house. The TPS position, which is a bit far from the building of the house. Reasons based on local wisdom of the Bugis place TPS at the front of the yard and away from the house building are as follows: (a) household waste, both dry and wet, is easy to dispose of at the TPS, (b) the pile of garbage at the TPS often causes foul odor, especially in the rainy season, and (c) when garbage is burned at polling stations, it will cause smoke and smoke to break down easily. From this description, it turns out that it can be understood that TPS from the local wisdom side of the Bugis Tribe, is really very wise. The trash in the TPS will not smell inside the house. Similarly, when the smoke when garbage is burned, the smoke will not enter the house because it decomposes quickly. That was caused by the position of the polling station is directly related to residential streets in front of the house. Besides TPS associated with large outside air and its potential to quickly decompose smoke into a wider space. From a technical and environmental perspective, the location of the TPS is at the front of the yard and away from the building. The technical reason is that the garbage at the TPS is easily taken by the garbage officer to go to the final landfill (TPA). From the environmental side, it is as follows: (a) solid waste is easily controlled, (b) if there is no garbage collector bringing garbage to the landfill, the garbage can be burned, and (c) the position of the TPS is directly related to the vast air, so that smoke and odors can be easily neutralized by larger air volume. Therefore it can be concluded that the location of small, medium, and large type of TPS based on local wisdom of the Bugis tribe is at the front of the yard and its position far from the house building. Such a position, easily controlled, facilitates the work of garbage workers, and is safe for the environment.

\subsection{Location of Green Open Land (Open Space) Small, Medium and Large Type Residential Homes}

Respondent data concerning the location of green open land, can be seen in the table 4 .

Table 4. Location of Green Open Land (Open Space) Type of Small, Medium and Large Residential Homes.

\begin{tabular}{lllll}
\hline Number & Description & Statement & Frequency & Percentage \\
\hline 1 & The front of the home page & Strongly agree & 177 & 59 \\
2 & The side of the house & Agree & 123 & 41 \\
3 & Backyard & Disagree & 0 & 0 \\
4 & Any place on the home page & Strongly disagree & 0 & 0 \\
5 & Total & & 300 & 100 \\
\hline
\end{tabular}

Source: Research Results.

Data obtained from 300 respondents are described as follows: A total of 177 respondents (59\%) stated that the location of open space of small type houses (types 54 and 60) based on the local wisdom of the Bugis Tribe is on the front (front of the home page). A total of 123 respondents (41\%) stated that the location of open space was on the side of the house (the side yard). Based on the local wisdom of the Bugis tribe, the reasons underlying the respondents' placing open space on the front and side pages of the house are: (a) making it easy for air to enter the house, (b) open space for fresh air providers, (c) open space as a playground children, (d) open space functions ecologically, and (d) open space also functions social and recreational. From the technical and environmental side, the location of open space, namely on the front and side of the house. The reasons or considerations are as follows: (a) open space provider of fresh air, (b) open space functions as an ecosystem or ecology and functions as a social facility, and (c) open space functions as recreation and is not difficult to maintain and clean. From the technical, environmental, and local wisdom aspects of the Bugis tribe, apparently open space has the same placement and function. Based on the previous description, it can be concluded that the location of the open space of small, medium and large types of houses based on the local wisdom of the Bugis Tribe is on the front and side or yard of the house. Its functions are as follows: (a) open space, a provider of fresh air, (b) open space functions ecosystem or ecology, and (c) open space functions as a social and recreational facility.

\subsection{Forms of Construction of Small, Medium and Large Type of Dwelling Septictank}

Respondent data concerning the form of septic tank construction, can be seen in the table 5 .

Table 5. Forms of Construction of Septictank Homes for Small, Medium and Large Types.

\begin{tabular}{llll}
\hline Number & Description & Statement & Frequency \\
\hline 1 & Rectangular with a brick or concrete pair construction & Strongly agree & 286 \\
2 & Round shape, concrete construction & Agree & 14 \\
3 & Any shape & Disagree & 0 \\
4 & Rectangular shape, local raw material & Strongly disagree & 4,67 \\
5 & Total & & 0 \\
\end{tabular}

Source: Research Results. 
Data obtained from 300 respondents are described as follows: A total of 286 respondents $(95.33 \%)$ stated that the form of septictank construction for small type houses (types 54 and 60) was rectangular with the construction of masonry or concrete stone pairs. The walls and floors are waterproof plastered, the coverings are of concrete construction, The depth of construction is approximately 2 meters, equipped with seepage construction, placed at the front of the house. A total of 14 respondents $(4.67 \%)$ stated that the shape of the septictank is round, concrete construction, and concrete cover. Judging from the local wisdom of the Bugis, the form of construction of small, medium and large type of residential septictank is rectangular with the construction of concrete masonry. The walls and floors are waterproof plastered, covered with concrete construction, The depth of construction is approximately 2 meters, equipped with seepage construction, placed in the front yard. The reasons underlying the respondent are: (a) human excrement or feces must have a good place, (b) the rectangular shape means land, water, air, and wind, so that this human waste must also return to its origin, namely to the universe. From a technical and environmental point of view, the form of septictank construction is as follows: (a) construction of masonry or concrete masonry, (b) waterproof plastered walls and floors, (c) coverings of concrete construction, (d) more or less construction depth 2 meters, and (e) equipped with seepage construction. On this basis it can be concluded that from the local wisdom side of the Bugis tribe, the form of septictank construction for small, medium, and large residential types is concrete stone construction completed with seepage construction. The shape of the construction is rectangular and the depth of construction is approximately 2 meters.

\subsection{Form of Construction of Dirty and Rainwater Sewerage for Small Type Residential Homes (Types 54 and 60)}

Respondent data concerning the form of construction of dirty water channels and rain water, can be seen in the table 6 .

Table 6. Forms of Construction of Dirty and Rainwater Sewers of Small Type Residential Houses (Types 54 and 60).

\begin{tabular}{llll}
\hline Number & Description & Statement & Frequency \\
\hline 1 & Open channel shape, construction of waterproof plastered masonry bricks & Strongly agree & 297 \\
2 & Open channel without construction & Agree & 3 \\
3 & Closed channel & Disagree & 0 \\
4 & Any shape & Strongly disagree & 0 \\
5 & Total & & 1 \\
\hline
\end{tabular}

Source: Research Results.

Data obtained from 300 respondents are described as follows: A total of 297 respondents (99\%) stated that the form of construction of sewerage and rainwater of small, medium and large type houses based on local wisdom of the Bugis tribe is the form of open channels, construction of masonry pairs waterproof plaster, or concrete construction. A total of 3 respondents ( $1 \%$ ) stated that the forms of sewerage and dirty water are open channels without construction. The reasons underlying the respondents to choose the form of an open channel with the construction of a waterproof plastered brick pair or concrete construction are: (a) the form of construction is easy to do and easy to maintain, (b) drain household waste water and rainwater well into an environment that is lower safely, (c) household waste water does not cause a foul odor, (d) rainwater does not inundate the yard, and (e) germs cannot reproduce. Viewed from the technical side, the form of sewerage and rainwater sewerage construction is in the form of open channels of brick or concrete construction. This kind of construction is durable, easy to maintain and control. From the economic side, the construction can be reached by all levels of society. In terms of environmental sustainability, the construction is durable and does not pollute the residential environment. From the health side, the construction improves the degree of public health. The physical environment of the house will look clean and healthy, so will the social environment better. Based on the foregoing description, it can be concluded that the forms of dirty water and rainwater of small, medium and large type of residential houses are open channels. Construction of a waterproof plastered brick pair.

\subsection{Forms of Construction of Small, Medium and Large Type of Temporary Garbage Dumps (TPS)}

Respondent data concerning the form of construction of temporary landfills, can be seen in the table 7 .

Table 7. Forms of Construction of Small, Medium and Large Type of Temporary Garbage Dumps (TPS).

\begin{tabular}{|c|c|c|c|c|}
\hline Number & Description & Statement & Frequency & Percentage \\
\hline 1 & Brick / concrete pair construction & Strongly agree & 280 & 93,33 \\
\hline 2 & Used wood, used drums, used plastic buckets, and the like & Agree & 20 & 6,67 \\
\hline 3 & Piling up in the home yard & Disagree & 0 & 0 \\
\hline 4 & Dig a hole in the yard & Strongly disagree & 0 & 0 \\
\hline 5 & Total & & 300 & 100 \\
\hline
\end{tabular}

Source: Research Results. 
Data obtained from 300 respondents are described as follows: A total of 280 respondents $(93.33 \%)$ stated that the form of small type TPS houses (types 54 and 60) based on the local wisdom of the Bugis tribe is in the form of a rectangular permanent shape. Construction of brick or concrete pairs, size $0.60 \times 0.60 \times 0.60$ meters. A total of 20 respondents $(6.67 \%)$ stated that the form is semi-permanent. Simple construction, namely from used wood, from used drom, used plastic buckets, and the like. The reasons underlying the respondents to choose permanent construction are (a) household waste, both dry and wet, is easy to dispose of at the polling station, (b) easy to maintain, (c) not too complicated and easy to clean. From a technical and environmental point of view, a permanent form of TPS is easy to make and hold, safe for the environment, easy to control, garbage officers are easier to collect garbage because garbage has been put together. From the economic side, the TPS can be reached by all levels of society. From the health side it can improve the degree of public health. On this basis it can be concluded that the form of small, medium and large type of house TPS based on local wisdom of the Bugis Tribe is permanent. From a technical point of view, it's easy to do and hold. From the economic side can be reached by all levels of society. From the environmental side, it can improve the quality of the environment.

\subsection{Form of Open Space Construction for Small Type Residential Homes (Types 54 and 60)}

Respondent data concerning forms of open space construction, can be seen in the table 8 .

Table 8. Forms of Open Space Residential Construction Types of Small, Medium and Large.

\begin{tabular}{llll}
\hline Number & Description & Statement & Frequency \\
\hline 1 & In the form of about $75 \%$ to $90 \%$ & Strongly agree & 294 \\
2 & Brick or concrete construction & Agree & 6 \\
3 & Any shape & Disagree & 0 \\
4 & Mostly constructed & Strongly disagree & 0 \\
5 & Total & & 0 \\
\hline
\end{tabular}

Source: Research Results.

Data obtained from 300 respondents are described as follows: A total of 294 respondents (98\%) stated the form of open space of small type houses (types 54 and 60) based on local wisdom. The reasons underlying respondents chose natural open space form are as follows: (a) ecological function of open space, which is a provider of fresh air, storing ground water, and the like, (b) open space for social and recreational functions, namely joking places, places children play, resting places enjoy fresh air and the wild, (c) open space functions economically, that is, can be planted with trees that produce fruit. From the technical and environmental side, the form of open space, which is generally naturally located on the front and sides of the house. The reasons or considerations are: (a) open space which provides fresh air, (b) open space functions as an ecosystem or ecology and functions as a social facility, and (c) open space is easy to maintain and clean. From the technical, environmental and local wisdom of the Bugis tribe, apparently open space has the same form and placement, as well as functions. On this basis, it can be concluded that the form of open space of small, medium, and large types of houses based on local wisdom of the Bugis tribe is natural in shape and with little brick or concrete construction. Open space has a very large function of life, which has ecological, social, recreational, and economic functions.

\section{Conclusion}

Conclution of this research is: 1) The location of the septictank construction is based on local wisdom of the Bugis tribe, small, medium and large type of dwellings are in the front yard of the house. Construction is a pair of bricks or concrete, rectangular in shape, and is equipped with permanent construction, 2) The location of sewerage and rainwater based on local wisdom of the Bugis Tribe, small, medium and large type of dwellings is on the right or left side of the house, leading to the front, which is on the lower part of the land or leads to drainage. This form of construction is a pair of waterproof plastered bricks, 3) The location of temporary landfills (TPS) based on local wisdom of the Bugis, small, medium and large type of dwellings is at the front of the yard of the house, located far from the building. This form of construction is a pair of bricks or concrete, and 4) The location and form of open spease based on local wisdom of the Bugis Tribe, small, medium and large type of dwellings are the front yard of the house. Form is largely natural, and a small portion is constructed.

\section{Acknowledgements}

The authors thank each of them to: 1) Rector of Makassar State University, 2) Directorate of Research and Community Service Directorate General of Strengthening Research and Technology Ministry of Research, Technology and Higher Education who has provided research funding in order to foster lecturer research at Higher Education, 3) Chairperson of the UNM Research and Community Service Institute (LP2M) for his direction as the person in charge of research and community service activities at UNM, 4) Secretary of the Research and Community Service Institute (LP2M) of UNM for technical guidance given during conducting research, 5) Regents of Bone, Soppeng, and Wajo who have provided 
information to conduct research in their target regions or districts, 6) Heads of the Resettlement and Targeting Services Offices of Bone, Soppeng and Wajo Regency for their willingness to become facilitators in research activities, and 7) All lecturers and students, as well as all parties who have taken part in carrying out this research.

\section{References}

[1] Undang-Undang R. I. Nomor 32 Tahun (2009). Tentang Perlindungan dan Pengelolaan Lingkungan Hidup.

[2] Trainer, Ted. (2011). The Radical Implication of a Zero Growth Economy

(http://rwer.wordpress.com/2011/09/06/rwer-issue-57-

Trainer/, diakses 15September 2018).

[3] Muhammad Ardi, Bakhrani A. Rauf, dan Mithen.(2017). Desain Rumah Tinggal Berbasis Kearifan lokal Suku Bugis Yang Berwawasan Lingkungan. Makassar: Badan Penerbit UNM.

[4] Marfai. (2012). Pengantar Etika Lingkungan dan Kearifan Lokal. Yogyakarta: UGM Press.

[5] Jundiani. (2018). Local Wisdom in the Environmental Protection and Management. ICon-ITSD IOP Publishing IOP Conf. Series: Earth and Environmental Science 175 (2018). 012130 doi: 10.1088/1755-1315/175/1/012130.

[6] Effendi Rayahu, Salsabila Hana, and Malik Abdul. (2018). Pemahaman Tentang Lingkungan Berkelanjutan. Modul, vol 18 no 2, issues period 2018 ISSN (P) 0853-2877 (E) 2598327X. http://ejournal.undip.ac.id/index.php/modul.

[7] Undang-Undang R. I. No. 4 Tahun (1992). Tentang Perumahan dan Permukiman.
[8] Haryanto, Sri Eko. (2018). Pengertian Rumah Tinggal. https://www.slideshare.net/wilem17.

[9] Tasdyanto (ed.). (2008). Kearifan Lingkungan Budaya Indonesia. Yogyakarta: Kementerian Negara Lingkungan Hidup.

[10] Adyana, P. (2012). Wacana Tembang Macapat sebagai Pengungkap Sistem Kognisi dan Kearifan Lokal Etnik Jawa. Publikasiilmiah.ums.ac.id. Volume 2. No. 22. Desember 2012.

[11] Hamzah, M. (2013). Pendidikan Lingkungan, Sekelumit Wawasan Pengantar. Bandung: Refika Aditama.

[12] Daud, Anwar. (2001). Dasar-dasar Kesehatan Lingkungan. Makassar: Fakultas Kesehatan Lingkungan Masyarakat UNHAS.

[13] Notoatmodjo, S. (2007). Promosi Kesehatan dan IlmuPerilaku. Jakarta: Rineka Cipta.

[14] Franceys, R., Pickford, J. \& Reed, R. (1992). A Guide to the Development of On-Site Sanitation, Geneva: World Health Organization.

[15] Khairil, Muhammad. (2018). Pengertian Lingkungan Hidup.://www.quipper.com/id.

[16] Adnani. (2011). Ilmu Kesehatan Masyarakat. Cetakan 1. Yogyakarta: Nuha Medika.

[17] World Commission on Environment and Development (WCED). (1987). Our Common Future. Oxford: Oxford University Press.

[18] Mesaki, Simeon; and Malipula, Mrisho. (2011). "Julius Nyerere's influence and legacy: From a Proponent of familyhood to a candidate for sainthood". International journal of Sociology and Antropology. Vol. 3 (3) pp. 093-100, March 2011. Available online https://academicjournals.org/journal/IJSA/articleabstract/7DBC2502079, diakses 22 April 2019. 